УДК 811.133.1'367'342.8

DOI https://doi.org/10.26661/2414-9594-2021-1-23

\title{
ЗВ'ЯЗНІСТЬ ДІАЛОГІЧНОГО МОВЛЕННЯ У СТРУКТУРІ РЕАЛІСТИЧНОЇ ПРОЗИ: ЛІНГВОКУЛЬТУРОЛОГІЧНИЙ ПОГЛЯД НА ПРОБЛЕМУ (НА МАТЕРІАЛІ РОМАНУ Р. М. ДЮ ГАРА «СІМ'Я ТІБО»)
}

\author{
Станіслав О. В. \\ доктор філологічних наук, дочент, \\ професор кафедри романських мов та інтерлінгвістики, \\ завідувач кафедри романських мов та інтерлінгвістики \\ Волинський національний університет імені Лесі Украӥнки \\ пр. Волі, 13, Луиьк, Україна \\ orcid.org/0000-0003-4600-5328 \\ olga.stanislav@ukr.net
}

\begin{abstract}
Ключові слова: художній діалог, синтаксична зв'язність, література реалізму, лінгвокультурологічний підхід, художня картина світу.
\end{abstract}

У фокусі нашої наукової розвідки - художнє діалогічне мовлення як форма комунікації, яка традиційно виступає невід'ємною частиною текстової тканини епічного твору, важливий засіб реалізації естетичної, стилістичної функцій тексту, ефективний спосіб творення самохарактеристики персонажів. Предметом нашого розгляду стали синтаксичні структури у структурі діалогів як лінгвокультурологічні виразники художньої картини світу. Проведений нами науковий пошук грунтується на дослідженнях В. Кухаренка, який аналізував діалогічне мовлення на лексичному рівні. У результаті узагальнень, на рівні синтаксису ми виокремили три яруси синтаксичних елементів, що становлять мовленнєву партію того чи іншого персонажа. Перший ярус, основу діалогічного мовлення становлять загальнорозмовні, широковживані синтаксичні структури розмовного мовлення. Другий ярус становлять соціально-групові й інші (професійні, гендерні, вікові тощо.) елементи, що визначають суспільне обличчя персонажа та є характерними для певної групи. Над ними надбудовується третій ярус, який відображає неповторну індивідуальність мовленнєвої системи (синтаксису, зокрема) конкретної особи.

Як приклади наповнення першого ярусу діалогічного мовлення назвемо: використання простих за структурою синтаксичних конструкцій, еліптичне усічення фрази, зменшення іiі довжини, різке скорочення вживання дієприкметникових, дієприслівникових зворотів, стягнуті заперечні форми, прямий порядок слів у разі утворення питальних фраз тощо. До другого ярусу ввійшли стилістично забарвленні синтаксичні структури (різного роду повтори, синтаксичний паралелізм, градація, риторичні звертання, риторичні питання, вигуки тощо), незначні порушення синтаксичної норми. До третього - індивідуалізаційного - синтаксичні елементи, що максимально наслідують, імітують усне мовлення, зберігають тон невимушеності, неофіційності, безпосередності, простоти.

Проведене дослідження засвідчило, що діалогічне мовлення у структурі художнього тексту реалістичної прози загалом базується на основі першого та другого ярусів синтаксичних елементів. Діалоги літератури реалізму мають здебільшого книжково-літературний характер, підпорядковані законам розвитку літературного письмового мовлення. Обгрунтовано, що у структурі художнього діалогу реалістичної прози зв'язність синтаксичних структур $є$ прямим чи опосередкованим відображенням основних тенденцій антропоцентричної художньої картини світу. 


\title{
COHESION OF DIALOGUE SPEECH IN THE STRUCTURE OF REALISTIC PROSE: LINGUISTIQUE AND CULTURAL VIEW ON THE PROBLEM (BASED ON THE NOVEL BY ROGER MARTIN DU GARD "THE THIBAULTS")
}

\author{
Stanislav O. V. \\ Doctor of Philology, Associate Professor, \\ Professor at the Romance Languages and Interlinguistics Department, \\ Head of the Romance Languages and Interlinguistics Department \\ Lesya Ukrainka National University \\ Voli avenue, 13, Lutsk, Ukraine \\ orcid.org/0000-0003-4600-5328 \\ olga.stanislav@ukr.net
}

Key words: artistic dialogue, syntactic coherence, literature of realism, linguo-cultural approach, artistic picture of world.
The focus of our scientific research is artistic dialogic speech as a form of communication, which is traditionally an integral part of the textual fabric of an epic work, an important means of implementing the aesthetic, stylistic functions of the text, an effective way to create self-characterization.

The subject of our consideration was syntactic structures in the structure of dialogues as linguistic and cultural expressions of the artistic picture of the world. Our scientific research is based on the research of V. Kucharenko, who analyzed dialogic speech at the lexical level. As a result of generalizations, at the level of syntax, we distinguish three tiers of syntactic elements that make up the speech part of a character. The first tier, the basis of dialogic speech is common, widely used syntactic structures of colloquial speech. The second tier consists of socio-group and other (professional, gender, age, etc.) elements that define the social face of the character and are characteristic of a particular group. Above them is added a third tier, which reflects the unique individuality of the speech system (syntax, in particular) of a particular person.

Examples offilling the first tier of dialogic speech include: the use of simple syntactic constructions, elliptical truncation of the phrase, reducing its length, a sharp reduction in the use of adjectives, adverbial inflections, contracted negative forms, direct word order in the formation of interrogative phrases and so on. The second tier included stylistically colored syntactic structures (various repetitions, syntactic parallelism, gradation, rhetorical appeals, rhetorical questions, exclamations, etc.), minor violations of syntactic norms. The third (individualizing) tier included, syntactic elements that mimic as much as possible mimic oral speech, maintaining a tone of ease, informality, immediacy, simplicity.

The study showed that dialogic speech in the structure of the literary text of realistic prose is based, in general, on the basis of the first and second tiers of syntactic elements. The dialogues of the literature of realism are mainly of a book-literary nature, subject to the laws of the development of literary written speech. It is substantiated that in the structure of the artistic dialogue of realistic prose the coherence of syntactic structures is a direct or indirect reflection of the main tendencies of the anthropocentric artistic picture of the world. 
Постановка проблеми. У фокусі нашої наукової розвідки - художнє діалогічне мовлення як форма комунікації, яка традиційно виступає невід'ємною частиною текстової тканини епічного твору, важливий засіб реалізації естетичної, стилістичної функцій тексту, ефективний спосіб творення самохарактеристики персонажів. Своєрідність діалогічного мовлення в художньому тексті полягає в його антропоцентричності, культурологічній значущості й можливості моделювати в особливій вербальній формі індивідуальну авторську картину світу.

Традиційно мовознавці аналізували діалог із погляду лексики, фонетики, прагматики, психології, гендерних особливостей тощо (Н. Арутюнова, Л. Виготський, Т. Винокур, М. Дем'яненко, Л. Зиндер, О. Леонтьєв, Л. Щерба й інші). Синтаксичні характеристики діалогічного мовлення залишалися дещо осторонь лінгвістичних пошуків. Ось чому предметом нашого розгляду стали синтаксичні конструкції у структурі діалогів французької літератури реалістичного напряму як лінгвокультурологічні виразники художньої картини світу.

Покликаючись на дослідження В. Кухаренка, який аналізував діалогічне мовлення на лексичному рівні [1, с. 156-169], можна провести паралель і на рівні синтаксису виокремити такі три яруси синтаксичних елементів, що становлять мовленнєву партію того чи іншого персонажа. Перший ярус, основу діалогічного мовлення становлять розмовні, широковживані синтаксичні структури розмовного мовлення. Другий ярус становлять соціально-групові й інші (професійні, гендерні, вікові тощо) елементи, що визначають суспільне обличчя персонажа та $\epsilon$ характерними для певної групи. Над ними надбудовується третій ярус, який відображає неповторну індивідуальність мовленнєвої системи (синтаксису, зокрема) конкретної особи.

Як приклади наповнення першого ярусу діалогічного мовлення назвемо: використання простих за структурою синтаксичних конструкцій, еліптичне усічення фрази, зменшення іiі довжини, різке скорочення вживання дієприкметникових, дієприслівникових зворотів, стягнуті заперечні форми, прямий порядок слів під час утворення питальних фраз тощо. До другого ярусу ввійдуть стилістично забарвленні синтаксичні структури (різного роду повтори, синтаксичний паралелізм, градація, риторичні звертання, риторичні питання, вигуки тощо), незначні порушення синтаксичної норми. До третього - індивідуалізувального, синтаксичні елементи, що максимально наслідують, імітують усне мовлення, зберігають тон невимушеності, неофіційності, безпосередності, простоти.

Мета статті. Отже, маємо на меті проаналізувати зразки діалогічного мовлення в романі
Роже Мартена дю Гара (Roger Martin du Gard, 1881-1958 рр.) «Сім’я Тібо» (“Les Thibault”) крізь призму лінгвокультурологічного сприйняття світу. Доведемо, що зразки діалогічного мовлення в літературі реалістичного напряму в основі своїй $\epsilon$ синтаксично зв'язними. У цьому сенсі аналіз діалогів становить найскладніше завдання, оскільки сама сутність цього поняття пов'язана 3 аналогом усного мовленням, яке характеризується спонтанністю, непідготовленістю, ситуативністю, афективністю i, як результат, часто позбавлене логічності викладу, чіткості структурування інформації, зв'язності. 3 іншого боку, обгрунтування зв'язності діалогічних реплік буде прямим, очевидним доказом того, що література реалістичного напряму XX ст. грунтується на синтагматичному типі синтаксису, який співвідноситься 3 лінгвокультурологічного погляду 3 антропоцентричною художньою картиною світу [2, с. 288].

Виклад основного матеріалу дослідження. Передусім нагадаємо, що Мартен дю Гар - яскравий представник сімейного роману французького реалізму XX ст., лауреат Нобелівської премії в галузі літератури 1937 р. за художню силу і правду зображення людини та найбільш суттєвих сторін сучасного життя. Автор обстоює своєю творчістю великі гуманістичні ідеали, світлу віру в людину, iii моральні цінності, високу духовність.

«Сім'я Тібо» стверджує реалістичні традиції французької літератури, водночас глибоко, по-сучасному, по-новаторськи вирішує гострі, нагальні завдання XX ст. Об'єктивність, історизм, діалектика художнього методу М. дю Гара, його намагання відтворити досвід цілої історичної епохи, пізнати світ і людину в ньому, осягнути закони еволюції, зв'язку окремих індивідуальностей 3 історією людства - усе це прямо й безпосередньо співвідноситься із ключовими положеннями антропологічної художньої картини світу. Стверджуючи принцип антропоцентричності, письменник на прикладі долі кожного із членів родини Тібо розкриває сенс людського буття, звеличує життя в його найвищому прояві - життя як творчість і людина як творець.

«Сім'я Тібо» - цілісний та чіткий за композицією твір. У його основу покладена сімейна хроніка - історія Оскара Тібо та його двох синів. Письменник передає об'єктивний, поступальний рух часу крізь складне сплетіння біографічного, історичного та сюжетного часу. Мартен дю Гар розглядає проблеми «людина і час», «людина й історія» як нові можливості, нові перспективи реалістичної прози в розкритті героїв.

Зауважимо, що такі відзнаки новітнього реалізму, як: водночас типізація й індивідуалізація образів, ієрархічна, послідовна зв'язність частин твору, заглибленість художнього мислення, 
сконцентрованість на описі внутрішнього стану героїв, тема наступності поколінь [3, с. 252], знаходять своє природне втілення в романі «Сім'я Тібо» та відтворюють принципи антропологічної культурної парадигми. Творча майстерність М. дю Гара засвідчує життєдайність оновлених реалістичних традицій у французькій літературі $\mathrm{XX}$ ст. Глибокий психологічний аналіз письменника уможливив створення різнобічного, інтелектуального, морального образу людини епохи, який тісно пов'язаний із віком складних політичних конфліктів, великих історичних змін та культурних новацій.

Спостережено, що в «Сім’ї Тібо» багато уваги відведено діалогам та внутрішнім монологам. На нашу думку, важливо також указати на таку специфічну ознаку діалогічного мовлення, як наявність авторських ремарок, що вводять репліки та виступають своєрідним когезійним засобом зв'язку реплік.

Перейдемо безпосередньо до аналізу фактичного матеріалу та розглянемо один зі зразків діалогічного мовлення в романі «Сім'я Тібо». 3 початку художньої оповіді автор знайомить нас iз головними персонажами твору за допомогою діалогу. Оскар Тібо зі своїм старшим сином Антуаном слідує до приміщення школи, де навчається його молодший син Жак, який не повернувся після занять додому:

- "Ah, cette fois, Antoine, non, cette fois, ça dépasse!". Le jeune homme ne répondit pas (1).

L'École était fermée. C'était dimanche, et il était neuf heures du soir. Un portier entrouvrit le guichet.

- "Savez-vous où est mon frère?" cria Antoine (2).

L'autre écarquilla les yeux.

M. Thibault frappa du pied.

- "Allez chercher l'abbé Binot" < ... > (3).

Quelques minutes passèrent. M. Thibault, essoufflé, s'était laissé chair sur une chaise ; il murmura de nouveau, les dents serrées:

- "Cette fois, tu sais, non, cette fois!" (4).

- "Excusez-nous, Monsieur", dit l'abbé Binot qui venait d'entrer sans bruit $<\ldots>(5)$.

- "Bonjour, jeune docteur! Qu'y a-t-il donc?" (6)

- "Où est mon frère?" (7).

- “Jacques?" (8).

- “Il n'est pas rentré de la journée!" s'écria M. Thibault, qui s'était levé (9).

- "Mais, où était-il allé?" fit l'abbé, sans trop de surprise (10).

- "Ici, parbleu! À la consigne!" (11).

L'abbé glissa ses mains sous sa ceinture:

- "Jacques n'était pas consigné” (12).

- "Quoi?” (13).

- “Jacques n'a pas paru à l'École aujourd'hui $<\ldots>$.. (14).

- "Jacques nous a dit hier qu'il avait quatre heures de consigne. Il est parti, ce matin, à l'heure habituelle. Et puis, vers onze heures, pendant que nous étions tous à la messe, il est revenu, paraît-il: il n'a trouvé que la cuisinière; il a dit qu'il ne reviendrait pas déjeuner parce qu'il avait huit heures de consigne au lieu de quatre" (15).

- "Pure invention", appuya l'abbé (16).

_ "J'ai dû sortir à la fin de l'après-midi", continua M. Thibault, "pour porter ma chronique à la Revue des Deux Mondes. Le directeur recevait, je ne suis rentré que pour le dîner. Jacques n'avait pas reparu. Huit heures et demie, personne. J'ai pris peur, j'ai envoyé chercher Antoine qui était de garde à son hopital. Et nous voilà" (17).

L'abbé pinçait les lèvres d'un air songeur. M. Thibault entrouvrit les cils, et décocha vers l'abbé puis vers son fils un regard aigu.

- "Alors, Antoine?" (18).

- "Eh bien, père", fit le jeune homme, "si c'est une escapade préméditée, cela écarte l'hypothèse d'accident" (19).

Son attitude invitait au calme. M. Thibault prit une chaise et s'assit; son esprit agile suivait diverses pistes; mais le visage, paralysé par la graisse, $n$ 'exprimait rien.

- "Alors", répéta-t-il, "que faire?" (20).

Antoine réfléchit.

- “Ce soir, rien. Attendre" (21) [4, c. 5-6].

Наведений фрагмент - це зразок діалогічного мовлення, яке складається із синтаксичних структур, що належать до різних ярусів. Нині мовленнєві репліки виступають вагомим чинником характеристики героїв твору, допомагають читачеві скласти цілісний образ кожного 3 них.

Мовні партії Антуана й абата Біно - це переважно структури першого i другого синтаксичних ярусів. Вони відзначаються чіткістю будови, логічністю утворення висловлень, які зумовлені прямим порядком слів $(14,19)$, використанням синтаксичного паралелізму, повторів $(2,7)$, простих, усічених речень $(8,16,21)$ тощо. Усі ці синтаксичні структури зв'язують структурно, композиційно, семантично окремі репліки в діалогічну форму мовлення і належать до синтагматичного типу синтаксису.

Мовлення Оскара Тібо виокремлюється особливим стилістичним забарвленням, складається зі синтаксичних структур як першого, так і другого та третього ярусів. Репліки $(15,17)$ є логічними, когезійно зв'язаними послідовним типом зв'язку. Такі експліцитні засоби зв'язності, як слова-замінники, кореляти (Jacques $<\ldots>$ Il $<\ldots>$ ), детермінативи (son hôpital), часові лексичні маркери (hier, ce matin, vers onze heures, à la fin de l'après-midi, huit heures et demie), лексеми на позначення місця (à la messe, à la Revue des Deux Mondes, à l' hôpital), сполучники та сполучникові звороти (Et puis <...>, Et voilà $<\ldots>$ ), інші уможливлюють структурну, композиційну, змістову єдність висловлень. Зазначимо, що діалогічне мовлення відбувається в одному лексико-семантичному полі, що також слугує зв'язності висловлень. Отже, заразом вони цілком відповідають першому та другому синтаксичним ярусам $\mathrm{i}$ синтагматичному типу синтаксису.

До синтаксичних структур третього рівня віднесемо, наприклад, повтор синтаксичної струк- 
тури - “Cette fois, tu sais, non, cette fois!'”, яка містить стилістичний плеоназм (лексему поn), який характеризує мовлення персонажа як емоційне, занадто збуджене. Відзначимо наказовий, підвищений тон мовлення Оскара Тібо ("Allez chercher l'abbé Binot”), отже, його нестриманість, навіть грубість, які експліцитно виразились за допомогою вигуків (“Ici, parbleu! A la consigne!”), еліптичних фраз (“Alors, Antoine?”; “Alors", “que faire?”), окличних речень тощо. Такі синтаксичні елементи не просто характеризують героя, а особливим чином індивідуалізують його, додають йому специфічності, оригінальності, винятковості.

Під час проведення аналізу діалогічного мовлення 3 погляду когезійних засобів вираження особливо важливо вказати на важливість імпліцитних просодичних способів зв'язування. Так, мовлення Антуана Тібо й абата Біно характеризується рівним, спокійним, врівноваженим тоном, що розкриває їх як людей стриманих, виважених. Репліки Оскара Тібо - навпаки, виказують важкий, нестриманий, запальний характер героя. Проте в будь-якому разі просодичні засоби когезії уможливлюють зв'язність окремих реплік у цілісний текст. Саме просодичні елементи розмовного мовлення перетворюють художнє діалогічне мовлення на живу, яскраву, динамічну частину загальної оповіді. Вони додають ритму, енергії, емоційної насиченості викладу або, навпаки, затягують, сповільнюють темп розповіді.

Результати дослідження вказують на суттєве когезійне значення авторських ремарок у структурі діалогічного мовлення. Установлено, що здебільшого до складу авторських ремарок входить такий експліцитний (лексико-граматичний) спосіб зв'язування, як стрижневе дієслово. Навколо нього формуються репліки того чи того сегмента діалогу. Серед дієслів, що виконують когезійну функцію в діалозі, превалюють слова зі значенням говоріння або їхні стилістичні синоніми. Наприклад, у наведеному діалозі таке вербальне ядро становлять répondre, crier, murmurer, dire, faire (y значенні parler), continuer (de parler). Вони когезійно зв'язують репліки у складі цілісного діалогічного мовлення, здійснюють портретизацію героїв, сприяють утворенню стилістичного контексту, збільшують інформативний обсяг, творять художню образність тексту загалом.

Висновки й перспективи подалыших розробок у цьому напрямі. Отже, проведена розвідка засвідчила, що діалогічне мовлення у структурі художнього тексту реалістичної прози формується загалом на основі першого та другого ярусів синтаксичних елементів. Діалоги літератури реалізму мають здебільшого книжково-літературний характер; вони підпорядковані законам розвитку літературного письмового мовлення. Дослідження виявило, що в поле зору французьких письменників-реалістів XX ст. активно потрапляють соціальні і суспільно значущі групові чинники, що впливають на мовлення героїв та $є$ особливо важливими для зображення цілісності характерів персонажів. Використання синтаксичних елементів першого та другого ярусів стверджує синтагматичний тип діалогічного мовлення у французькій літературі реалізму, отже, синтаксичну зв'язність висловлень. Обгрунтовано, що у структурі художнього діалогу реалістичної прози зв'язність синтаксичних структур є прямим чи опосередкованим відображенням основних тенденцій антропоцентричної художньої картини світу. Перспективними вбачаємо наукові пошуки в напрямі дослідження особливостей синтаксичних структур у літературі інших художніх жанрів та напрямів у площині лінгвокультурологічного аналізу.

\section{ЛIТЕРАТУРА}

1. Кухаренко В. Інтерпретація тексту. Вінниця : Нова книга, 2004. 261 с.

2. Станіслав О. Психолінгвістичні особливості синтаксичної когезії у структурі художнього внутрішнього мовлення (на матеріалі французької літератури потоку свідомості). Наукові записки. Серія «Філологічна». Острог : Вид-во Нац. ун-ту «Острозька академія», 2015. Вип. 56. С. 286-289.

3. Руднев В. Словарь культуры XX в. Москва, 1997. URL: http://www.philosophy.ru/.

\section{ПЕРЕЛІК ВИКОРИСТАНИХ ДЖЕРЕЛ}

4. Martin du Gard R. Les Thibault. Paris : Éditions Gallimard, 1995. 436 p.

\section{REFERENCES}

1. Kukharenko V.A. (2004) Interpretatsciia tekstu. [Interpretation of the text]. Vinnytsia: Nova kn. 261 p.

2. Stanislav O.V. (2015) Psykholinhvistychni osoblyvosti syntaksychnoi kohezii u strukturi khudozhnoho vnutrishnioho movlennia (na materiali franctsuzkoi literatury potoku svidomosti). [Psycholinguistic features of syntactic cohesion in the structure of artistic internal speech (on the material of French literature of the flow of consciousness)]. Proceedings. Philological series. Ostroh: Nat. University "Ostroh Academy". Vol. 56. P. 286-289.

3. Slovar kultury XX veka (1997) [Dictionary of culture of the twentieth century] / comp. V. Rudnev. Moscow. URL: http://www.philosophy.ru/.

\section{LIST OF SOURCES}

4. Martin du Gard R. Les Thibault. Paris : Éditions Gallimard, 1995. 436 p. 